\title{
ISOLASI DAN IDENTIFIKASI SENYAWA FENOLIK DARI KULIT AKAR TUMBUHAN Artocarpus dadah Miq.
}

\author{
Indarto \\ Program Studi Pendidikan Fisika, FTK IAIN Raden Intan Lampung; e-mail: indartoalkimia@yahoo.com
}

Diterima: 3 Agustus 2015 Disetujui: 11 Oktober 2015. Dipublikasikan: Oktober 2015

\begin{abstract}
Artocarpus plant dadah Miq. is one of the species of Artocarpus of the Moraceae family that belongs to a rare plant in nature. This plant is known as the main source of phenolic derivative compound that is flavone compound in or tri-oxygenated and terisoprenilasi in C-3 position, and also known as the main source of phenolic compound derived flavonoids, aryl-benzofuran, stilbenoid and xanthane flavonoida, which have biological activity as promoters antitumor, antibacterial, antifungal, antiimflamatori, antikanker and others. This study aimed to isolate and identify the phenolic compounds contained in plant A. dadah obtained from the village of Purwoasri, North Metro District, Metro City, Lampung Province. Research stages include collection and sample preparation and extraction, isolation, and purification of compounds using $K C V$ method, flash chromatography , KKG, and TLC, while the identification of compounds is performed using ultraviolet-visible (UV-VIS) and infrared (IR) spectroscopy. In the present study, three compounds were isolated, one of which was estimated to be flavonoid compounds based on UV-VIS and IR spectra data which also had high activity against murine leukemia P-388 cells with IC 503.1 $\mu \mathrm{g} / \mathrm{mL}$. Based on the IR spectral data for the other two compounds there is a-OH uptake in the region of 3200-3500 cm $\mathrm{cm}^{-1}, C=C$ aromatic uptake in the area of $1600-1400 \mathrm{~cm}^{-1}$, so it is estimated that both compounds are phenolic group compounds.
\end{abstract}

\begin{abstract}
Abstrak: Tumbuhan Artocarpus dadah Miq.merupakan salah satu spesies Artocarpus dari famili Moraceae yang termasuk tumbuhan langka di alam. Tumbuhan ini dikenal sebagai sumber utama senyawa turunan fenolik yaitu senyawa flavon $d i$ atau tri-oksigenasi dan terisoprenilasi pada posisi C3, dan juga dikenal sebagai sumber utama senyawa fenolik turunan flavonoid, aril-benzofuran, stilbenoid dan santon turunan flavonoida, yang memiliki aktivitas biologi sebagai promotor antitumor, antibakteri, antifungal, antiimflamatori, antikanker dan lain-lain.Penelitian ini bertujuan untuk mengisolasi dan mengidentifikasi senyawa fenolik yang terkandung dalam tumbuhan $A$. dadah yang diperoleh dari desa Purwoasri, Kecamatan Metro Utara, Kota Metro, Provinsi Lampung.Tahapan penelitian yang dilakukan meliputi pengumpulan dan persiapan sampel kemudian ekstraksi, isolasi, dan pemurnian senyawa menggunakan metode $\mathrm{KCV}$, kromatografi flash, KKG, dan KLT, sedangkan identifikasi senyawa dilakukan menggunakan spektroskopi ultraungu-tampak (UV-VIS) dan inframerah (IR). Pada penelitian ini telah berhasil diisolasi tiga senyawa, yang salah satunya diperkirakan senyawa flavonoid berdasarkan data spektrum UV-VIS dan IR yang juga memiliki aktivitas tinggi terhadap sel murine leukemia P-388 dengan $\mathrm{IC}_{50} 3,1 \mu \mathrm{g} / \mathrm{mL}$. Berdasarkan data spektrum IR untuk dua senyawa yang lain terdapat serapan -OH pada daerah $3200-3500 \mathrm{~cm}^{-1}$, serapan $\mathrm{C}=\mathrm{C}$ aromatik di daerah $1600-1400 \mathrm{~cm}^{-1}$, sehingga diperkirakan kedua senyawa tersebut merupakan senyawa golongan fenolik.
\end{abstract}

Kata Kunci: artocarpus dadah, fenolik, isolasi

\section{PENDAHULUAN}

Indonesia merupakan negara tropis yang kaya akan sumber daya alam terutama tumbuhan (Simanullang, Afifuddin, \& Lubis, n.d.). Indonesia dikenal sebagai megabiodiversity terbesar ke dua di dunia setelah Brasilia (Akhsa, Pitopang, \& Syariful, 2015; Ersam, 2004). Tumbuhan merupakan sumber bahan kimia hayati (chemical 
resources), sehingga biodiversitas dapat dipandang sebagai suatu industri atau pabrik bahan kimiawi yang berproduksi sepanjang tahun menghasilkan bahan kimia berguna (Chemical Prospectives) (Matsjeh, 2009) melalui proses rekayasa bioteknologi alami.

Tumbuhan Artocarpus dadah Miq. merupakan salah satu spesies dari Artocarpus yang termasuk tumbuhan langka dialam. A. dadah ini merupakan tumbuhan yang endemik hanya di Indonesia dan masih sedikit sekali orang yang meneliti (Suhartati \& Yandri, 2007). A. Dadah dikenal sebagai sumber utama senyawa turunan fenolik yaitu senyawa flavon $d i$ atau tri-oksigenasi dan terisoprenilasi pada posisi C-3 Ersam dikutip (Suhartati \& Yandri, 2007) Tumbuhan A. dadah ini juga dikenal sebagai sumber utama senyawa fenolik turunan flavonoid, aril-benzofuran, stilbenoid dan santon turunan flavonoida, yang memiliki aktivitas biologi sebagai promotor antitumor, antibakteri, antifungal, antiimflamatori, antikanker dan lainlain (Ersam, 2004). Oleh sebab itu perlu dilakukan penelitian terhadap tumbuhan Artocarpusini, khususnya A. dadah.

Senyawa fenolik terdiri dari beragam senyawa dengan ciri yang sama, yaitu cincin aromatik yang mempunyai satu atau lebih substituen hidroksil. Senyawa fenolik banyak diteliti karena diketahui mempunyai aktivitas biologis dan efek farmakologi yang menarik, seperti antibakteri (Bokel, Diyasena, Leslie, Gunatilaha, \& Sotheeswaran, 1988; Huang, Mao, \& Gui-Fang, 2001; Sultanbawa, Surendrakumar, \& Bladon, 1987).

Dari fraksinasi ekstrak etilasetat A. dadah telah berhasil diisolasi tiga turunan stilbenoid terprenilasi baru yaitu 3- $(\gamma, \gamma-$ dimetilalil) resveratrol, 5- $(\gamma, \gamma-$ dimetilalil) oksiresveratrol, 3-(2,3dihidroksi-3-metilbutil) resveratrol, dan satu turunan benzofuran baru, 3$(\gamma, \gamma$-dimetilpropenil) moracin $\mathrm{M}$. Senyawa-senyawa fenolik yang ditemukan pada tumbuhan tropika Indonesia mempunyai tingkat oksidasi yang lebih maju dibandingkan tumbuhan dari tempat lain, keadaan geologis yang berbeda akan mempengaruhi kandungan senyawa dalam suatu tumbuhan (Ersam, 2004). Peneliti akan mengisolasi senyawa pada Artocarpusini khususnya $A$. dadah dengan menggunakan spektrum UV-VIS dan IR khususnya di desa Purwoasri, Kecamatan Metro Utara, Kota Metro, Provinsi Lampung.

\section{BAHAN DAN METODE Bahan}

Bahan kimia yang dipakai meliputi diklorometana, etil asetat, metanol, $n$-heksana, aseton, akuades, serium sulfat $1,5 \%$ dalam $\mathrm{H}_{2} \mathrm{SO}_{4} 2 \mathrm{~N}$, $\mathrm{NaCl} 1 \%$, silika gel Merck G 60 untuk $\mathrm{KCV}$, silika gel Merck 60 (35-70 Mesh) untuk KKG, untuk KLT digunakan plat KLT silika gel Merck kiesegal $60 \quad \mathrm{~F}_{254}$ 0,25 mm. Pereaksi geser untuk analisis spektrofotometer ultraungu-tampak adalah natrium hidroksida.

\section{Metode Pengumpulan dan persiapan sampel}

Sampel berupa kulit akar $A$. dadah diambil dari akar tumbuhan $A$. dadah dan dipisahkan antara kulit akar dan kayunya. Kulit akar lalu dibersihkan dan dipotong kecil-kecil. Sampel kulit akar yang telah dipotong kemudian dikering-anginkan. Kulit batang yang telah kering kemudian 
dihaluskan hingga berbentuk serbuk halus.

\section{Ekstraksi dengan metanol}

Sebanyak 2,4 kg kulit akar $A$. dadah yang telah dihaluskan, dimaserasi selama 24 jam dengan sekali maserasi sebanyak 200 gram, maserasi dilakukan sebanyak tiga kali. Ekstrak metanol yang diperoleh disaring kemudian dipekatkan dengan menggunakan penguap putar vakum pada suhu $45-50^{\circ} \mathrm{C}$ dengan laju putaran 120-150 rpm. Ekstrak pekat metanol tersebut ditambahkan $\mathrm{NaCl}$ $1 \%$ sebanyak $20 \%$ dari volume ekstrak metanol dan kemudian dipartisi dengan diklorometana-etilasetat $20 \%$. Hasil partisi tersebut kemudian dipekatkan kembali dengan menggunakan penguap putar vakum pada suhu $30-40^{\circ} \mathrm{C}$ dengan kecepatan 120-150 rpm.

\section{Kromatografi cair vakum (KCV)}

Ekstrak kasar hasil partisi dengan etilasetat dilarutkan dalam aseton kemudian difraksinasi dengan $\mathrm{KCV}$. Terlebih dahulu fasa diam silika gel Merck G 60 sebanyak 10 kali berat sampel dimasukkan ke dalam kolom. Kemudian kolom dikemas kering dalam keadaan vakum menggunakan alat vakum. Eluen yang kepolarannya rendah, dimasukkan ke permukaan silika gel terlebih dahulu kemudian divakum kembali. Kolom dihisap sampai kering dengan alat vakum dan siap digunakan.

Ekstrak kasar yang telah dilarutkan dalam aseton dan diimpregnasikan kepada silika gel, kemudian dimasukkan pada bagian atas kolom yang telah berisi fasa diam dan kemudian dihisap secara perlahanlahan ke dalam kemasan dengan cara memvakumkannya. Setelah itu kolom dielusi dengan metanol-diklorometana
$10 \%$ sampai dengan metanol $100 \%$. Kolom dihisap sampai kering pada setiap penambahan eluen (tiap kali elusi dilakukan). Kemudian fraksifraksi yang terbentuk dikumpulkan berdasarkan pola fraksinasinya. Fraksinasi sampel dengan teknik KCV dilakukan berulang kali dengan perlakuan yang sama seperti tahapan KCV awal.

\section{Kromatografi lapis tipis (KLT)}

Sebelum difraksinasi, terlebih dahulu dilakukan uji KLT untuk melihat pola pemisahan komponenkomponen senyawa yang terdapat dalam ekstrak kasar. Uji KLT juga dilakukan terhadap fraksi-fraksi yang akan difraksinasi dan juga fraksi-fraksi yang didapat setelah perlakuan fraksinasi. Uji KLT dilakukan menggunakan sistem campuran eluen menggunakan pelarut $n$-heksana, etilasetat, aseton, diklorometana, dan metanol. Hasil kromatogram diamati di bawah lampu UV dengan panjang gelombang $254 \mathrm{~nm}$ agar dapat dilihat pola pemisahan komponen-komponen senyawanya. Hasil kromatogram tersebut kemudian disemprot menggunakan larutan serium sulfat untuk menampakkan bercak/noda dari komponen senyawa tersebut. Setiap fraksi yang menghasilkan pola pemisahan dengan $\mathrm{Rf}$ (Retention factor) yang sama pada kromatogram, digabung dan dipekatkan sehingga diperoleh beberapa fraksi gabungan yang akan difraksinasi lebih lanjut.

\section{Kromatografi flash}

Kromatografi flash digunakan untuk memisahkan ekstrak sampel dengan kuantitas yang tidak terlalu besar. Teknik yang dilakukan sama seperti pada KCV. Ekstrak hasil KCV yang telah dilarutkan dalam aseton dan diimpregnasikan kepada silika gel, 
kemudian dimasukkan pada bagian atas kolom yang telah berisi fasa diam. Setelah itu kolom dielusi dengan eluen yang cocok dari hasil KLT sebelum fraksinasi, dimulai dari yang kepolarannya rendah kemudian ditingkatkan kepolarannya. Kolom diberi tekanan dari atas kolom, sehingga eluen akan terdorong cepat turun ke bawah. Kolom jangan sampai kering pada setiap penambahan eluen (tiap kali elusi dilakukan). Kemudian fraksi-fraksi yang terbentuk dikumpulkan berdasarkan pola fraksinasinya. Fraksinasi sampel dengan teknik kromatografi flash dilakukan berulang kali dengan perlakuan yang sama seperti tahapan awal.

\section{Kromatografi kolom gravitasi (KKG)}

Setelah dihasilkan fraksi-fraksi dengan jumlah yang lebih sedikit, tahapan fraksinasi selanjutnya dilakukan menggunakan teknik kromatografi kolom gravitasi (KKG). Fasa diam silika gel Merck (35-70 Mesh) dilarutkan dalam pelarut yang akan digunakan dalam proses pengelusian. Campuran tersebut diaduk hingga diperoleh suatu slurry, campuran tersebut dimasukkan ke dalam kolom dan diusahakan agar kolom tidak kehabisan pelarut. Kemudian atur fasa diam hingga rapat (tidak berongga) dan rata. Selanjutnya masukkan sampel yang telah dijerapkan pada silika gel ke dalam kolom yang telah berisi fasa diam. Pada saat sampel dimasukkan, usahakan agar kolom tidak kering/kehabisan pelarut karena akan mengganggu fasa diam yang telah dikemas rapat, sehingga proses elusi tidak akan terganggu.

\section{Uji kemurnian}

Uji kemurnian dilakukan dengan metode KLT dan uji titik leleh.Uji kemurnian secara KLT menggunakan beberapa campuran eluen. Kemurnian suatu senyawa ditunjukkan dengan timbulnya satu noda dengan berbagai campuran eluen yang digunakan, dengan pengamatan noda dilakukan di bawah lampu UV dengan panjang gelombang $254 \mathrm{~nm}$ dan kemudian disemprot menggunakan larutan serium sulfat untuk menampakkan bercak/noda dari komponen senyawa tersebut.

Untuk uji titik leleh, sebelum dilakukan pengukuran, alat pengukur titik leleh tersebut dibersihkan terlebih dahulu dari pengotor yang ada.Selanjutnya, untuk kristal yang berukuran besar, kristal terlebih dahulu digerus hingga berbentuk serbuk. Kemudian kristal yang akan ditentukan titik lelehnya diletakkan pada lempeng kaca, diambil sedikit dengan menggunakan pipet kapiler, alat dihidupkan dan titik leleh diamati dengan bantuan kaca pembesar. Suhu pada saat kristal pertama kali meleleh, itulah titik leleh dari senyawa tersebut. Pengukuran titik leleh dilakukan sebanyak tiga kali. Apabila menunjukan titik leleh yang sama, maka dapat disimpulkan bahwa senyawa yang diperoleh sudah murni.

\section{Spektrofotometer ultraungu- tampak (UV-VIS)}

Sampel berupa kristal murni sebanyak 0,0001 gram dilarutkan dalam $10 \mathrm{~mL}$ metanol. Larutan ini digunakan sebagai persediaan untuk beberapa kali pengukuran. Pertama, sampel diukur serapan maksimumnya dalam metanol. Selanjutnya larutan persediaan dibagi menjadi beberapa bagian. Kemudian masing-masing larutan persediaan ditambah dengan 
pereaksi-pereaksi geser sepertinatrium hidroksida $(\mathrm{NaOH})$, kemudian larutan diukur serapan maksimumnya.

\section{Spektrofotometer inframerah (IR)}

Sampel kristal hasil isolasi yang telah murni dianalisis menggunakan spektrofotometer inframerah. Kristal yang telah murni dibebaskan dari air kemudian digerus bersama-sama dengan halida anorganik, KBr. Gerusan kristal murni dengan $\mathrm{KBr}$ dibentuk menjadi lempeng tipis atau pelet dengan bantuan alat penekan berkekuatan 8-10 ton per satuan luas. Kemudian pelet tersebut diukur puncak serapannya.

\section{HASIL DAN PEMBAHASAN}

Pada penelitian ini membagi 2400 gram sampel ke dalam 200 gram untuk satu tahap maserasi, sehingga ada 12 tahap maserasi. Satu tahap maserasi perlakukannya selama 24 jam dengan tiga kali pengulangan. Maserasi menggunakan pelarut metanol, pemilihan pelarut ini dikarenakan senyawa fenolik merupakan senyawa polar, sehingga untuk mengekstrak senyawa polar diperlukan pelarut yang juga polar.Kemudian menyaring dan menguapkan hasil ekstraksi menggunakan penguap putar vakum pada suhu $45-50^{\circ} \mathrm{C}$ dengan laju putaran 120-150 rpm.

Pada penguapan dengan alat penguap putar vakum ini diperoleh ekstrak pekat sampel hasil maserasi metanol. Kemudian menambahkan $\mathrm{NaCl} 1 \%$ sebanyak $20 \%$ dari volume ekstrak metanol ke dalam ekstrak metanol dan kemudian mempartisinya dengan diklorometana/etilasetat $20 \%$.Penambahan $\mathrm{NaCl} 1 \%$ bertujuan untuk mengendapkan tanin yang ada, sehingga tidak ikut terekstrak oleh diklorometana/etil asetat 20\%.Pada awalnya partisi menggunakan etil asetat, tetapi karena ekstrak metanol dengan etil asetat menyatu dan tidak terpisah sehingga ditambahkan diklorometana supaya terpisah membentuk dua cairan yang tidak saling bercampur. Penggunaan etil asetat untuk partisi ekstrak metanol karena kandungan air dalam ekstrak metanol tersebut masih cukup banyak, sehingga untuk memisahkannya dengan cara partisi ini. Etil asetat akan mengekstrak senyawa organiknya dan terpisah dari air. Kepolarannya tidak terlalu besar sehingga dapat meminimalkan tertariknya senyawasenyawa yang sangat polar.Setelah itu,menguapkan kembali dengan menggunakan penguap putar vakum pada suhu $30-40^{\circ} \mathrm{C}$ dengan kecepatan 120-150 rpm.

Dari proses penguapan dengan alat penguap putar vakum ini menghasilkan ekstrak etil asetat sebanyak 151,28 gram. Ekstrak ini kemudian dilihat pola pemisahan komponen-komponen senyawanya menggunakan kromatografi lapis tipis (KLT). Eluen yang digunakan untuk KLT adalah metanol/diklorometana $10 \%$ dengan fasa diam Silika Gel Merck 60 GF254 0,25mm.

Sebanyak 151,28 gram ekstrak etil asetat ini kemudian dilakukan fraksinasi menggunakan teknik kromatografi cair vakum (KCV) dengan caramembagi menjadi 4 tahap $\mathrm{KCV}$, pembagian menjadi 4 tahap $\mathrm{KCV}$ dimaksudkan karena keterbatasan alat KCV yang tidak bisa menampung sampel secara keseluruhan. KCV tahap pertama menggunakan 31,5 gram ekstrak kering, KCV tahap kedua 14,7 gram, KCV tahap ketiga 48 gram, dan KCV tahap keempat menggunakan sisanya yaitu 57,08 gram. Pada setiap tahapan di atas, ekstrak kering dilarutkan 
dalam aseton kemudian diimpregnasi pada Silika Gel Merck 60 (35-70 Mesh). Setelah itu fraksinasi dengan cara KCV, dimana proses awal setelah mendapatkan hasil impregnasi ekstrak terhadap Silika Gel adalah mempersiapkan kolom kromatografinya, diawali dengan alat kromatografi yang dirangkai sedemikian rupa. Pembuatan kolom silika, dengan cara memadatkan silika agar tidak pecah saat kromatografi. Setelah itu baru memasukkan hasil impregnasinya, dan kemudian mengelusi dengan eluen yang digunakan.

Eluen yang digunakan untuk masing-masing tahap adalah campuran metanol/diklorometana, dari $0 \%$ metanol sampai $100 \%$ metanol $(0 \%$ $100 \%$ ) yang ditingkatkan kepolarannya secara bertahap. Proses KCV awal ini untuk tahap 1 sebanyak 31,5 gram ekstrak menghasilkan 8 fraksi yang selanjutnya disederhanakan menjadi 4 fraksi utama berdasarkan pola KLT yaituA1 (1-2), B1 (3-4), C1 (5-6), dan D1 (7-8). Tahap 2 sebanyak 14,7 gram ekstrak menghasilkan 6 fraksi yang selanjutnya disederhanakan menjadi 3 fraksi utama yaitu A2 (1), B2 (2-4), dan C2 (5-6). Tahap 3 sebanyak 48 gram ekstrak menghasilkan 12 fraksi yang selanjutnya disederhanakan menjadi 4 fraksi utama yaitu A3 (1-3), B3 (4-8), C3 (9-10), dan D3 (11-12). Untuk tahap 4 sebanyak 57,08 gram ekstrak menghasilkan 12 fraksi yang selanjutnya disederhanakan menjadi 4 fraksi utama yaitu fraksi A4 (1-3), B4 (4-6), C4 (7-10), dan D4 (11-12). Setelah fraksinasi, selanjutnya adalah mengidentifikasi hasil fraksinasi dengan KL. Fraksi-fraksi yang diperoleh kemudian dilakukan pemisahan lebih lanjut hingga diperoleh tiga senyawa yang murni yaitu C1B2, C523 dan 8BB.

\section{Analisis Spektrometri \\ 1. Analisis Spektrometri Ultraungu-Tampak}

Senyawa flavonoid mempunyai sistem karbonil yang berkonjugasi dengan cincin aromatik, sehingga senyawa ini menyerap sinar pada panjang gelombang tertentu di daerah ultraungu (Tati Suhartati dan Yandri A.S). Senyawa flavon mempunyai serapan di daerah UV pada dua panjang gelombang, yaitu sekitar 310$350 \mathrm{~nm}$ pada pita I dan sekitar 250-280 nm pada pita II (Markham, 1988).

Gambar 1 memperlihatkan data serapan senyawa hasil isolasi C1B2 yang diperoleh dari kulit akar tumbuhan A. dadah terhadap sinar UV yang memberikan serapan maksimum

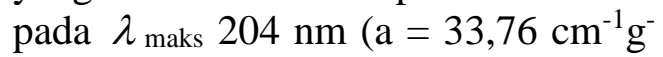
$\left.{ }^{1} \mathrm{~L}\right), 279 \mathrm{~nm}\left(\mathrm{a}=33,48 \mathrm{~cm}^{-1} \mathrm{~g}^{-1} \mathrm{~L}\right)$, dan $328 \mathrm{~nm}\left(\mathrm{a}=11,80 \mathrm{~cm}^{-1} \mathrm{~g}^{-1} \mathrm{~L}\right)$ dalam metanol dengan konsentrasi 0,0001 $\mathrm{g} / 0,01 \mathrm{~L} \quad(0,1 \mathrm{mg} / 10 \mathrm{~mL})$. Data spektrum UV menunjukkan karakteristik serapan untuk senyawa flavon. Serapan maksimum di daerah ultraviolet pada $\lambda_{\text {maks }} 328 \mathrm{~nm}$ merupakan spektrum khas flavon pada pita I yang karakteristik untuk resonansi gugus sinamoil dari cincin B. Serapan maksimum pada $\lambda$ maks $279 \mathrm{~nm}$ merupakan spektrum khas flavon pada pita II yang karakteristik untuk resonansi gugus benzoil dari cincin A. 


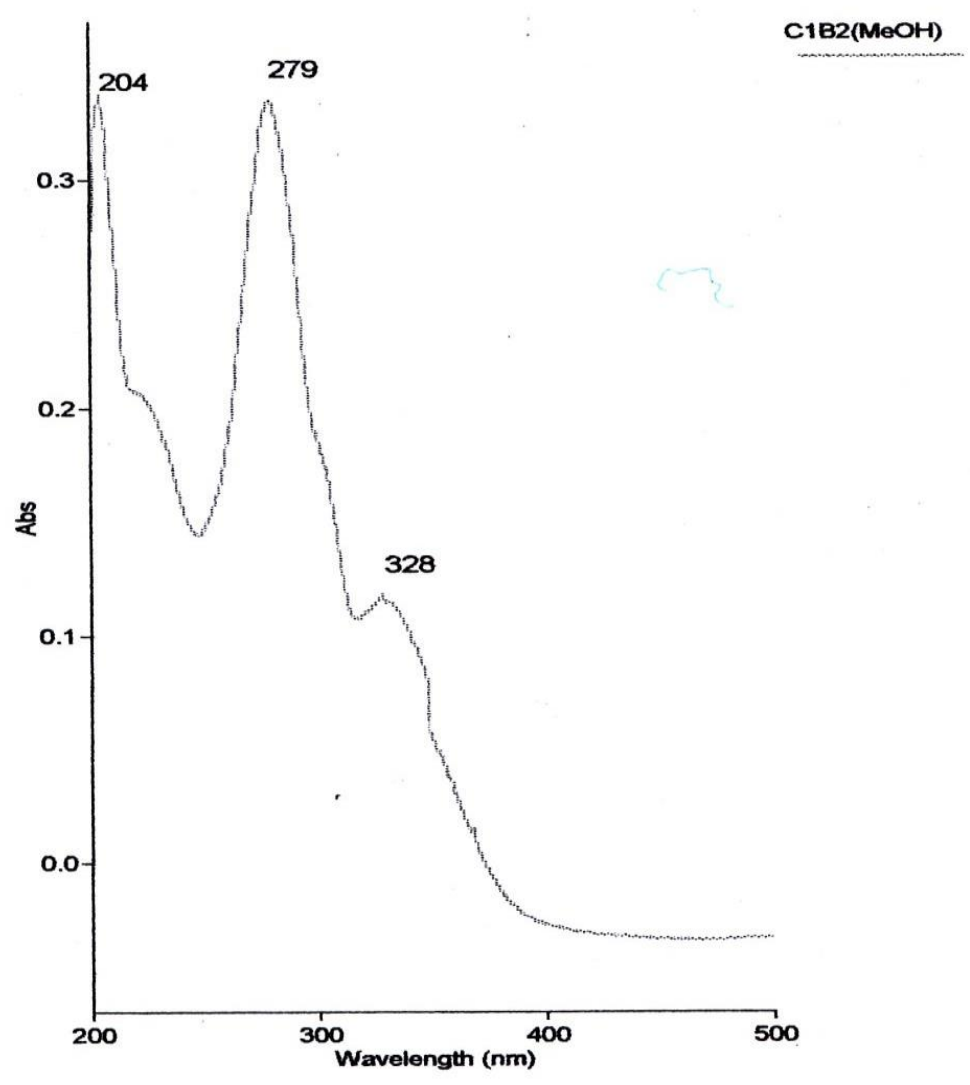

Gambar 1. Spektrum UV senyawa hasil isolasi C1B2 dalam metanol (Ilham, n.d.)

Untuk menentukan kedudukan gugus hidroksil fenol pada senyawa flavonoid dilakukan dengan penambahan pereaksi geser pada pengukurannya, yaitu dengan cara mengamati pergeseran puncak yang terjadi. Pereaksi geser $\mathrm{NaOH}$ digunakan untuk mendeteksi gugus hidroksil yang lebih asam dan tidak tersubstitusi. Adanya pergeseran batokromik pada pita I menunjukkan adanya gugus hidroksil pada posisi $\mathrm{C}_{3}$, $\mathrm{C}_{4}$, dan $\mathrm{C}_{7}$ (Markham, 1988).
Data spektrum UV pada penambahan pereaksi geser natrium hidroksida $(\mathrm{NaOH})$ terjadi pergeseran puncak serapan pada pita I sebesar 40 $\mathrm{nm}$ yaitu dari $328 \mathrm{~nm}$ bergeser menjadi $368 \mathrm{~nm}$ (Gambar 2). Adanya pergeseran batokromik pada pita I memberikan petunjuk adanya gugus hidroksil pada posisi $\mathrm{C}_{3}, \mathrm{C}_{4}$, dan $\mathrm{C}_{7 .}$.Senyawa hasil isolasi C523 dan 8BB belum dilakukan analisis spektroskopi UV-VIS. 


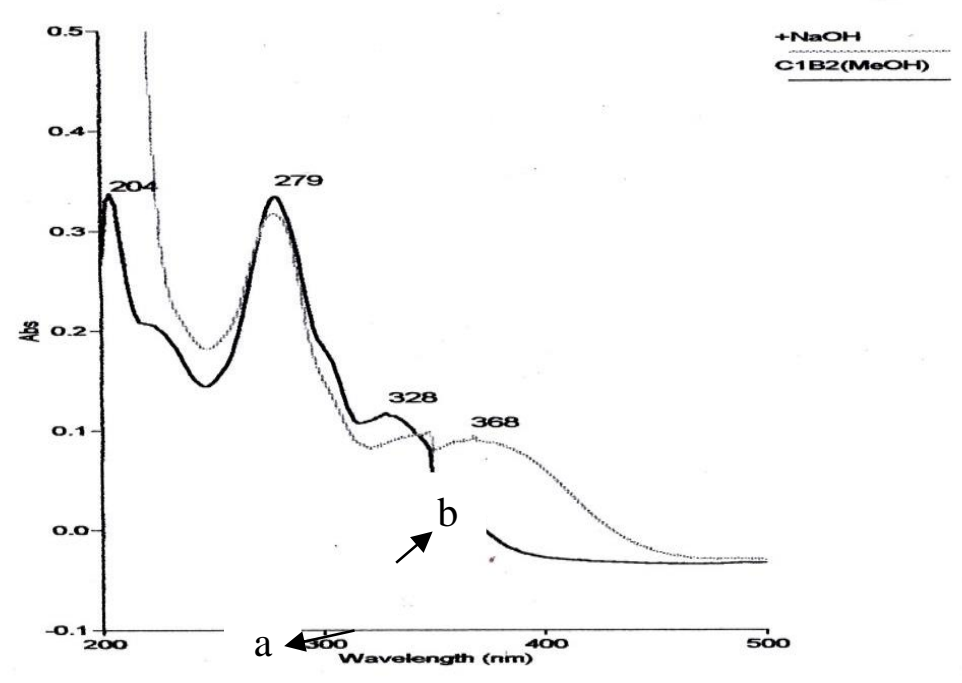

Gambar 2. Spektrum UV senyawa hasil isolasi C1B2 (a) dalam $\mathrm{MeOH}$, (b) dalam $\mathrm{MeOH}+\mathrm{NaOH}$ (Edhi, n.d.)

\section{Analisis spektrometri inframerah}

Dari data spektrum inframerah (IR) senyawa hasil isolasi C1B2 dapat diketahui adanya pita melebar pada daerah bilangan gelombang 3200$3600 \mathrm{~cm}^{-1}$ yang merupakan vibrasi ulur dari gugus hidroksil yang dapat membentuk ikatan hidrogen. Puncak serapan pada daerah $2975 \mathrm{~cm}^{-1}$ dan $2924 \mathrm{~cm}^{-1}$ merupakan petunjuk adanya gugus $\mathrm{C}-\mathrm{H}$ alifatik. Puncak serapan pada daerah bilangan gelombang 1655 $\mathrm{cm}^{-1}$ menunjukkan adanya gugus karbonil $(\mathrm{C}=\mathrm{O})$ yang berkonjugasi dengan $\mathrm{C}=\mathrm{C}$. Puncak-puncak serapan pada daerah 1619 dan $1466 \mathrm{~cm}^{-}$
${ }^{1}$ menunjukkan adanya $\mathrm{C}=\mathrm{C}$ aromatik, hal ini diperkuat dengan adanya serapan $\mathrm{C}-\mathrm{H}$ aromatik pada bilangan gelombang 900-600 $\mathrm{cm}^{-1}$. Puncak serapan pada bilangan gelombang 1352, 1298, dan $1243 \mathrm{~cm}^{-1}$ menunjukkan uluran ikatan C-O alkohol. Spektrum IR senyawa hasil isolasi dapat dilihat pada Gambar 3.

Dari data spektrum UV dan IR senyawa hasil isolasi C1B2 dari kulit akar tumbuhan $A$. dadah menunjukkan adanya kerangka fenolik dan diperkirakan termasuk golongan flavonoid.

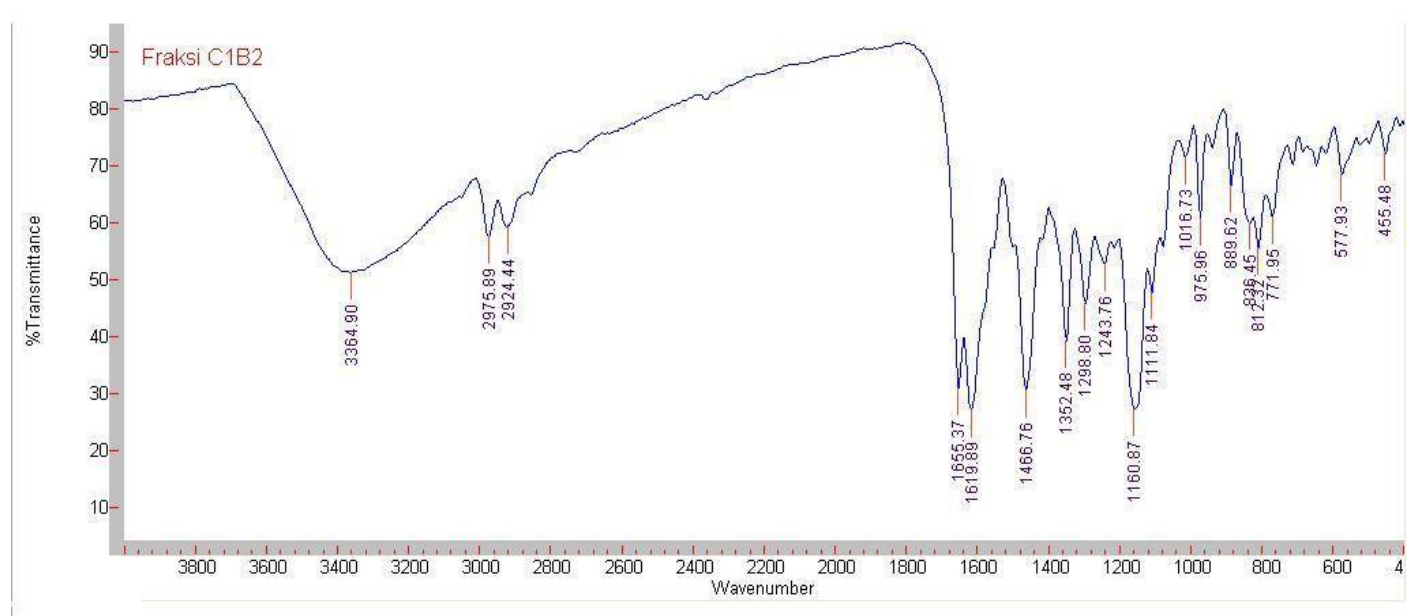

Gambar 3. Spektrum IR senyawa hasil isolasi C1B2 (Laili, n.d.) 
Dari data spektrum inframerah (IR) senyawa hasil isolasi C523 dapat diketahui adanya pita melebar pada daerah bilangan gelombang 3300$3500 \mathrm{~cm}^{-1}$ yang merupakan vibrasi ulur dari gugus hidroksil yang dapat membentuk ikatan hidrogen. Puncak serapan pada daerah $2931 \mathrm{~cm}^{-}$ ${ }^{1}$ merupakan petunjuk adanya gugus $\mathrm{C}$ $\mathrm{H}$ alifatik. Puncak-puncak serapan pada daerah 1612, 1517, dan $1471 \mathrm{~cm}^{-}$ ${ }^{1}$ menunjukkan adanya $\mathrm{C}=\mathrm{C}$ aromatik, hal ini diperkuat dengan adanya serapan $\mathrm{C}-\mathrm{H}$ aromatik pada bilangan gelombang 900-600 $\mathrm{cm}^{-1}$. Puncak serapan pada bilangan gelombang 1389 dan $1248 \mathrm{~cm}^{-1}$ menunjukkan uluran ikatan C-O alkohol. Dari data spektrum IR menunjukkan bahwa senyawa hasil isolai C523 memiliki kerangka fenolik. Spektrum IR senyawa hasil isolasi dapat dilihat pada Gambar4.

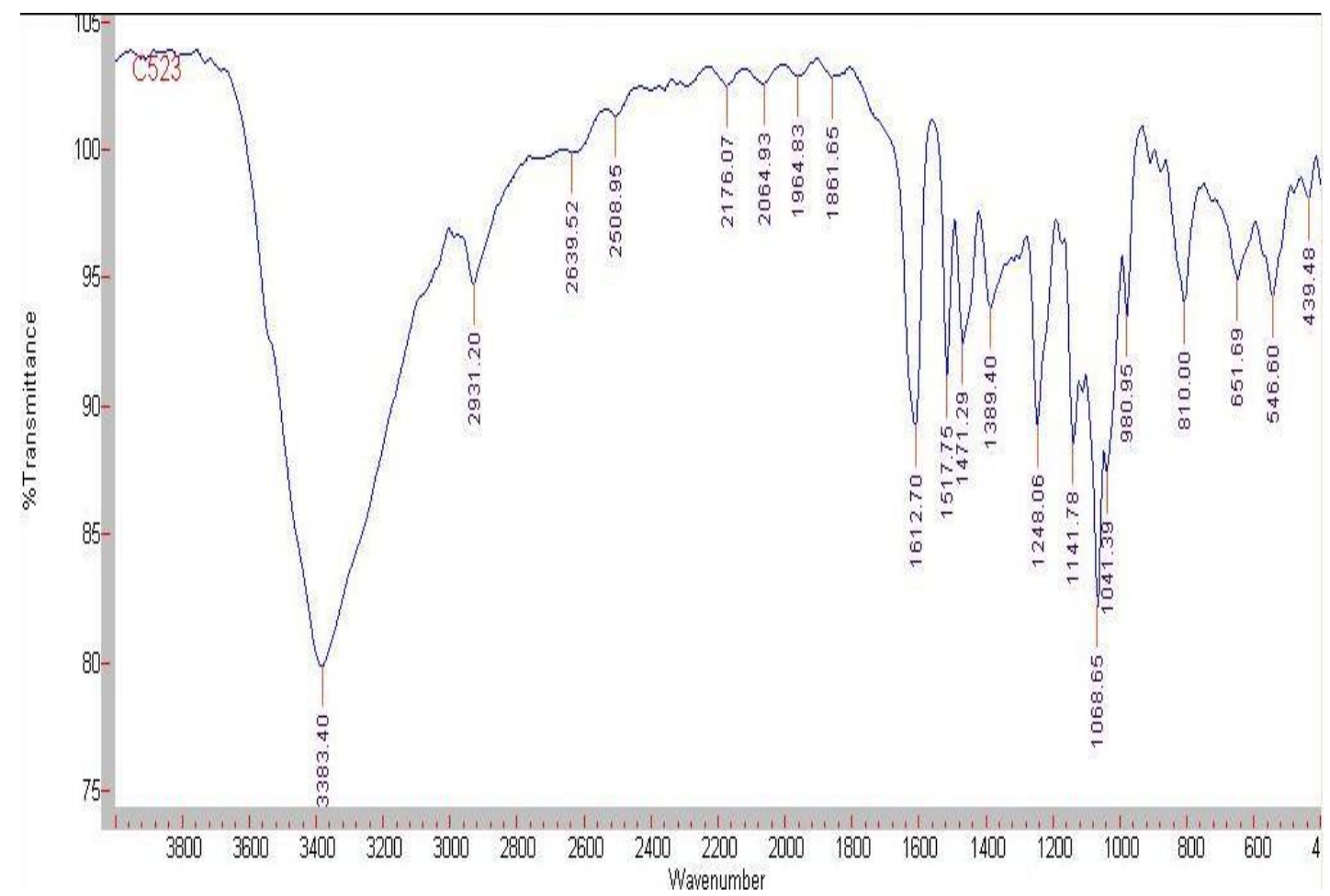

Gambar 4. Spektrum IR senyawa hasil isolasi C523 (Fitriyana, n.d.)

Dari data spektrum inframerah (IR) senyawa hasil isolasi 8BB dapat diketahui adanya pita melebar pada daerah bilangan gelombang 3200$3500 \mathrm{~cm}^{-1}$ yang merupakan vibrasi ulur dari gugus hidroksil yang dapat membentuk ikatan hidrogen. Puncak serapan pada daerah $2936 \mathrm{~cm}^{-1}$ dan $2767 \mathrm{~cm}^{-1}$ merupakan petunjuk adanya gugus $\mathrm{C}-\mathrm{H}$ alifatik. Puncak-puncak serapan pada daerah 1626,1522 , dan $1467 \mathrm{~cm}^{-1}$ menunjukkan adanya $\mathrm{C}=\mathrm{C}$ aromatik, hal ini diperkuat dengan adanya serapan $\mathrm{C}-\mathrm{H}$ aromatik pada bilangan gelombang 900-600 $\mathrm{cm}^{-1}$. Puncak serapan pada bilangan gelombang 1376, 1288, dan $1243 \mathrm{~cm}^{-1}$ menunjukkan uluran ikatan C-O alkohol. Dari data spektrum IR menunjukkan bahwa senyawa hasil isolai 8BB memiliki kerangka fenolik. Spektrum IR senyawa hasil isolasi dapat dilihat pada Gambar 5. 


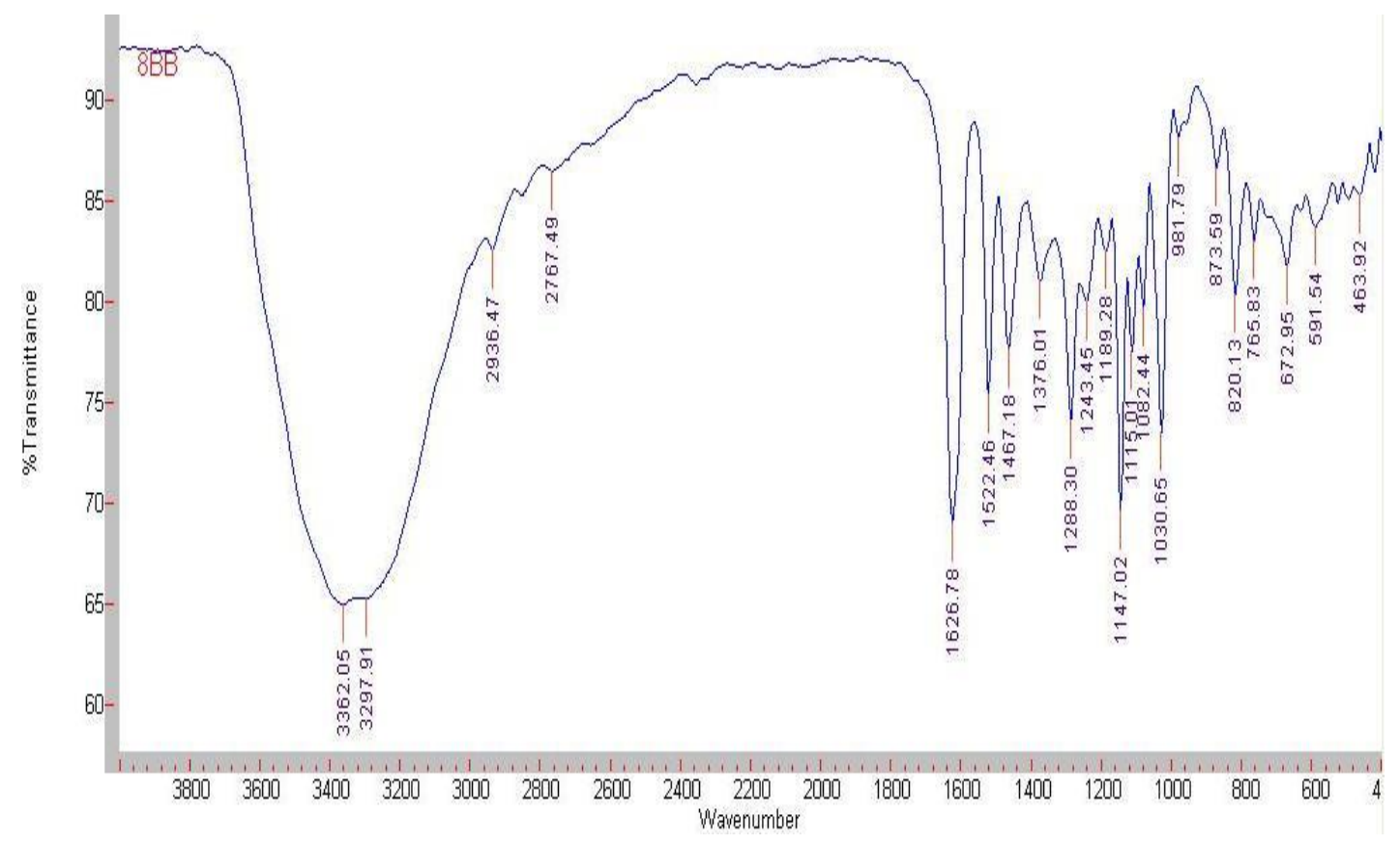

Gambar 5. Spektrum IR senyawa hasil isolasi 8BB (Kirana, n.d.)

Dari ketiga senyawa yang berhasil diisolasi dari kulit akar tumbuhan A. dadah, senyawa hasil isolasi C1B2 telah dilakukan pemeriksaan aktivitas terhadap sel murine leukemia P-388, dan hasilnya menunjukkan aktivitas yang tinggi dengan $\mathrm{IC}_{50} 3,1 \mu \mathrm{g} / \mathrm{mL}$. Sedangkan untuk kedua senyawa yang lain belum dilakukan pemeriksaan aktivitas terhadap sel murine leukemia P-388.

\section{SIMPULAN}

Pada penelitian ini telah berhasil diisolasi tiga senyawa, yang salah satunya diperkirakan senyawa flavonoid berdasarkan data spektrum UV-VIS dan IR yang juga memiliki aktivitas tinggi terhadap sel murine leukemia $\mathrm{P}-388$ dengan $\mathrm{IC}_{50} \quad 3,1$ $\mu \mathrm{g} / \mathrm{mL}$. Berdasarkan data spektrum IR untuk dua senyawa yang lain terdapat serapan -OH pada daerah 3200-3500 $\mathrm{cm}^{-1}$, serapan $\mathrm{C}=\mathrm{C}$ aromatik di daerah 1600-1400 $\mathrm{cm}^{-1}, \quad$ sehingga diperkirakan kedua senyawa tersebut merupakan senyawa golongan fenolik.

\section{DAFTAR PUSTAKA}

Akhsa, M., Pitopang, R., \& Syariful, A. (2015). Studi Etnobiologi Bahan Obat-Obatan Pada Masyarakat Kabupaten Tojo Una Una Sulawesi Tengah. Biocelebes, 9(1), 58-72.

Bokel, M., Diyasena, M. N. ., Leslie, A. ., Gunatilaha, \& Sotheeswaran, S. (1988). Canaliculatol, An Antifungal Resveratrol Trimer From Stemonoporous Canaliculatus. Phytochemistry, 27(2), 377-380.

Edhi, A. Spektrum UV senyawa hasil isolasi C1B2. Retrieved from https://www.google.co.id/search $? \mathrm{q}=$ gambar+Spektrum+UV+seny awa+hasil+isolasi+C1B2+MeO $\mathrm{H} \% 2 \mathrm{BNaOH} \& \mathrm{tbm}$

Ersam, T. (2004). Keunggulan Biodiversitas Hutan Tropika Indonesia Dalam Merekayasa 
Model Molekul Alami. Prosiding Seminar Nasional Kimia VI, 112.

Fitriyana. Spektrum IR senyawa hasil isolasi C523. Retrieved from https://www.google.co.id/search ?biw $=1366 \&$ bih $=659 \&$ tbm $=$ isch $\& s a=1 \& q=$ gambar + Spektrum $+\mathrm{I}$ $\mathrm{R}+$ senyawa+hasil+isolasi+C1B2 $+\& o q=$ gambar+Spektrum+IR+se nyawa+hasil+isolasi+C1B2

Huang, K., Mao, L., \& Gui-Fang, C. (2001). Anti-Inflammatory Tetramers Of Resveratrol From The Roots Of Visit Amurensis And The Seven Membered Ring In Some Oligostilbenes. Phytochemistry, 58, 357-362.

Ilham. Spektrum UV senyawa hasil isolasi C1B2 dalam metanol. Retrieved from https://www.google.co.id/search $? \mathrm{q}=$ gambar+Spektrum+UV+seny awa+hasil+isolasi+C1B2+MeO $\mathrm{H}$

Kirana, S. Spektrum IR senyawa hasil isolasi 8BB. Retrieved from https://www.google.co.id/search ?biw $=608 \&$ bih $=636 \&$ tbm $=$ isch $\& s a=1 \& q=$ gambar+Spektrum $+\mathrm{I}$ $\mathrm{R}+$ senyawa+hasil+isolasi $+8 \mathrm{BB}$

Laili, M. Spektrum IR senyawa hasil isolasi C1B2. Retrieved from https://www.google.co.id/search ?biw $=1366 \&$ bih $=659 \&$ tbm $=$ isch $\& s a=1 \& q=$ gambar + Spektrum $+\mathrm{I}$ $\mathrm{R}+$ senyawa+hasil+isolasi+C1B2

Markham, K. . (1988). Cara Mengidentifikasi Flavonoid. Bandung: ITB.

Matsjeh, S. (2009). Pemanfaatan Bahan Alam Nabati Yang Berpotensi Sebagai Bahan Baku Senyawa Obat. Seminar Nasional Pengembangan Farmasi Masaengembangan Farmasi Masa.

Simanullang, Y., Afifuddin, Y., \&
Lubis, A. H. (n.d.). Eksplorasi Tumbuhan Beracun Pada Taman Nasional Gunung Leuser Resort Sei Betung Sumatera Utara, 112.

Suhartati, T., \& Yandri, A. . (2007). Sikloartobilosanton Dari Kulit Batang Dan Flavonoid Dalam Beberapa Bagian Tumbuhan Artocarpus dadah Yang Tumbuh Di Lampung. J. Sains MIPA, 13(2), 82-86.

Sultanbawa, M. U. ., Surendrakumar, S., \& Bladon, P. (1987). Distichol, An Antibacterial Polyphenol From Shorea Disticha. Phytochemistry, 26(3), 799-801. 